\title{
Effects of chronic low carbonate saturation levels on the distribution, growth and skeletal chemistry of deep-sea corals and other seamount megabenthos
}

\author{
Ronald E. Thresher ${ }^{1, *}$, Bronte Tilbrook ${ }^{2}$, Stewart Fallon ${ }^{3}$, Nick C. Wilson ${ }^{4}$, \\ Jess Adkins ${ }^{5}$ \\ ${ }^{1}$ CSIRO Climate Adaptation Flagship, GPO Box 1538, Hobart, Tasmania 7001, Australia \\ ${ }^{2}$ CSIRO Wealth from Oceans Flagship and Antarctic Climate and Ecosystem Co-operative Research Centre, Hobart, \\ Tasmania 7001, Australia \\ ${ }^{3}$ Research School of Earth Sciences, Australian National University, Canberra, Australian Capital Territory 0200, Australia \\ ${ }^{4}$ CSIRO Process Science Engineering, Clayton, Victoria 3169, Australia \\ ${ }^{5}$ California Institute of Technology, Pasadena, California 91125, USA
}

\begin{abstract}
Ocean acidification has been predicted to reduce the ability of marine organisms to produce carbonate skeletons, threatening their long-term viability and severely impacting marine ecosystems. Corals, as ecosystem engineers, have been identified as particularly vulnerable and important. To determine the sensitivity of corals and allied taxa to long-term exposure to very low carbonate concentrations, we examined the distribution and skeletal characteristics of coral taxa along a natural deep-sea concentration gradient on seamounts of SW Australia. Carbonate undersaturation had little evident effect on the depth distribution, growth or skeletal composition of live scleractinians or gorgonians, with corals growing, often abundantly, in waters as much as 20 to $30 \%$ under-saturated. Developmental anomalies in the deepest skeleton-forming anthozoan collected (an isidid gorgonian, at nearly $4 \mathrm{~km}$ depth) suggest an absolute low tolerance limit of about $40 \%$ under-saturation. Evidence for an effect of acidification on the accumulation of reef structure is ambiguous, with clear indications of dissolution of high-magnesium calcite (HMC) gorgonian skeletons at depths below $2300 \mathrm{~m}$, but also abundant, old scleractinian skeletons well below the aragonite saturation horizon. The latter might be the result of ferromanganese deposition on exposed skeletons, which, however, may render them inhospitable for benthic organisms.
\end{abstract}

KEY WORDS: Anthozoa - Echinoderm · Aragonite saturation horizon · Calcite saturation horizon · Gorgonacea $\cdot$ High-magnesium calcite $\cdot$ Mineralogy $\cdot$ Scleractinia

\section{INTRODUCTION}

Ocean acidification results from net uptake by the ocean of carbon dioxide $\left(\mathrm{CO}_{2}\right)$ emissions, which causes a decrease in the carbonate ion concentration of ocean waters (Feely et al. 2004). This decrease has been forecast to hamper production of biogenic car- bonates (aragonite and calcite) in the skeletons, shells and tests of marine taxa (Orr et al. 2005, Moy et al. 2009), including shallow- and deep-water corals. The predicted impacts on reefs include reduced rates of calcification (Langdon \& Atkinson 2005), for which there may be evidence on shallow reefs (De'ath et al. 2009); shifts in community composition towards taxa 
that are more resilient or lack carbonate skeletons; and reduced long-term viability due to the additional stress imposed on reef taxa by changing carbonate concentrations (Hoegh-Guldberg et al. 2007, Guinotte \& Fabry 2008, Riegl et al. 2009, Veron et al. 2009). If reef ecosystems degrade as predicted under present 'business-as-usual' scenarios, the impacts on global biodiversity and regional economies will be profound.

Coral reefs in the deep sea have been identified as particularly vulnerable, due to low pre-industrial carbonate levels in their environment that will potentially be reduced even further as a result of climate change (Guinotte et al. 2006, Turley et al. 2007, Riegl et al. 2009). Direct tests of this sensitivity have not been done, but in at least one relatively shallow coldwater coral, Lophelia pertusa, calcification rates decline as predicted under low $\mathrm{pH}$ conditions (Maier et al. 2009). Deep-water corals may often also have very limited scope for vertical adjustment, potentially being squeezed between seamount summits on the one hand and shoaling saturation horizons on the other. Even the tops of many seamounts that currently support deep-sea coral communities may well be under-saturated in the next 50 to $100 \mathrm{yr}$. With nowhere to go, these cold-water reefs could 'simply disappear' (Poloczanska et al. 2007).

These predictions are based primarily on modelling studies and short-term laboratory exposure to low-carbonate conditions (Riegl et al. 2009, Veron et al. 2009, Ries et al. 2010). Their relevance to longterm exposure in the field and the potential for ecological or evolutionary adjustment are uncertain (Maynard et al. 2008). To partly fill this gap, we examined the distribution, growth and skeletal composition of corals and associated megabenthos on seamounts off Tasmania, Australia. These seamounts are of volcanic origin, come to within ca. $750 \mathrm{~m}$ of the surface, and support an extensive benthic community, dominated at depths $<1300 \mathrm{~m}$ by the reefforming scleractinians Solenosmilia variabilis and Enallopsammia rostrata, and deeper by hormathiid anemones, bathylasmatid barnacles and isidid gorgonians (Koslow et al. 2001, Althaus et al. 2009, Thresher et al. 2011a). Historical analyses of the regional water column, modelling and water samples taken close to the bottom for this project (see 'Results') show that the seamounts bracket carbonate conditions that range from saturated with respect to aragonite to under-saturated even with respect to calcite, the less soluble polymorph of calcium carbonate. We used this natural carbonate concentration gradient to test 2 hypotheses: (1) that carbonate saturation state is a factor constraining the depth distributions of calcifying taxa; and (2) that coral growth rates and skeletal densities decline as saturation levels fall, reflecting an increasing metabolic cost of calcification.

\section{MATERIALS AND METHODS}

Distributional data, samples from precisely known depths for skeletal and growth rate analysis, and water samples taken close to the substrata for carbonate analyses were obtained using the remotely operated vehicle (ROV) 'Jason'. The latter were taken 2 to $3 \mathrm{~m}$ above the seamount substratum, but near-bottom currents on most dives suggested that water close to the bottom was mixed. Dive details are provided in Table 1. In aggregate, the dives spanned a depth range of 729 to $4011 \mathrm{~m}$, and both the aragonite saturation horizon (ASH) and calcite saturation horizon (CSH) (see 'Results').

Carbonate chemistry close to the seamount was determined from 11 water samples collected 2 to $3 \mathrm{~m}$ above the substratum using the Niskin bottle sampler on board the ROV 'Jason'. Samples were taken opportunistically during the dive program, were obtained from a number of seamounts, and in aggregate covered a depth range of 951 to $3501 \mathrm{~m}$. Results from these analyses were compared to those from water samples taken from 3 ship-based hydrocasts in the seamount area (at $44^{\circ} 50.0^{\prime} \mathrm{S}, 145^{\circ} 44.99^{\prime} \mathrm{E}$; $44^{\circ} 20.5^{\prime} \mathrm{S}, 147^{\circ} 16.5^{\prime} \mathrm{E}$; and $44^{\circ} 18.44^{\prime} \mathrm{S}, 147^{\circ} 18.8^{\prime} \mathrm{E}$ ), which jointly spanned a depth range of 100 to $3547 \mathrm{~m}$. All samples were taken in austral midsummer (December 2008 and January 2009). Water samples were analysed for total dissolved inorganic carbon by coulometry and for total alkalinity by potentiometric titration following standard procedures (Dickson et al. 2007). The accuracy and precision of both methods are estimated to be $\pm 2 \mu \mathrm{mol} \mathrm{kg}{ }^{-1}$, based on duplicate analyses and comparison with certified reference material from Scripps Institution of Oceanography, California, USA. The saturation states for aragonite and calcite were calculated at in situ pressure in accordance with Lewis \& Wallace (1998), with carbonate equilibrium constants from Mehrbach et al. (1973), as refit by Dickson \& Millero (1987).

Maximum depth of each identifiable taxon (see Table 2) was determined from notes made on each dive, from analysis of high-resolution photographs made during the dives, and from samples collected for taxonomic, palaeoclimatic and ecological studies. Data were collected for all common megabenthos, but particular attention during the surveys was paid 
to cnidarians in general and anthozoans in particular. Taxonomic resolution was to nominal species for the 4 scleractinian corals present in the area, but only to genus (or higher) level or to conspicuous morphotype (assumed to be species) for most other groups. This reflects the limit of identification possible from field observations.

Mineralogy was based in part on the literature (e.g. Lowenstam \& Weiner 1989, Cairns \& MacIntyre 1992), but was also verified specifically for specimens in our study area and at the depths surveyed using $\mathrm{X}$-ray diffraction (XRD), followed by X-ray fluorescence (XRF) or wavelength dispersive electron probe microanalysis (WD-EPMA) (depending on the size of the sample) to quantify magnesium:calcium (Mg:Ca) and strontium:calcium (Sr:Ca) ratios (see Table 3). Wherever possible (most anthozoan taxa), we analysed a specimen taken close to the maximum depth at which each taxon was observed, to take into account possible changes in skeletal composition with increasing depth. For XRD, the bulk samples were pulverised down to a powder with a final grain size of $<5$ to $10 \mu \mathrm{m}$, back-pressed into standard aluminium XRD sample holders and then XRD data sets were collected with a Philips X'Pert Pro Diffractometer operating with Bragg-Brentano configuration and using Copper $\mathrm{K}$ radiation. The incident beam consisted of a $0.04 \mathrm{rad}$ Soller slit and a $1^{\circ}$ fixed divergence slit. The divergent beam consisted of a $0.3 \mathrm{~mm}$ receiving slit, a $0.04 \mathrm{rad}$ Soller slit, a $1^{\circ}$ anti-scatter slit, a curved graphite monochromator and a PW1711 proportional detector. Diffraction peaks were identified using Topaz software and phases identified using the ICDD database. XRF was done on approximately $0.4 \pm 0.0001 \mathrm{~g}$ of each sample put into $95 \%$ $\mathrm{Pt} / \mathrm{Au}$ crucibles with approximately $4.0 \pm 0.0001 \mathrm{~g}$ of 57:43 lithium borate flux. The mixture was fused into a homogeneous glass over an oxy-propane flame at a temperature of approximately $1050^{\circ} \mathrm{C}$. The molten material was then poured into a $30 \mathrm{~mm}$ diameter $95 \% \mathrm{Pt} / \mathrm{Au}$ mould heated to a similar temperature. Air jets then cooled the melt until the glass beads were cool to the touch. The resulting glass discs were analysed on a Philips PW2404 XRF system using a control program developed by Philips and a quantitative analysis method ('Mineral Salts') developed by CSIRO Process Science Engineering. In samples too small for $\mathrm{XRF}, \mathrm{Mg}: \mathrm{Ca}$ and $\mathrm{Sr}$ :Ca ratios were measured using WD-EPMA, following procedures in Thresher et al. (2007). WD-EPMA was also used to measure average skeletal $\mathrm{Mg}$ :Ca ratios for bamboo corals (Isididae; Gorgonacea) collected at different depths, from a series of analyses for each specimen that spanned its radial growth axis (Thresher et al. 2007).

Isidid growth rates were assessed using ${ }^{14} \mathrm{C}$ analysis, either following procedures detailed in Sherwood et al. (2009) for shallow-water specimens or, for deeper specimens, by comparing radiocarbon dates of calcite sections taken near the edge and centre of the coral's skeleton. Age was determined from the difference between the 2 dates, corrected to the full radius of the coral. This age estimate assumes that ${ }^{14} \mathrm{C}$ reservoir ages for ambient water have remained constant during the coral's lifetime. Skeletal densities were measured by weighing sections of the coral's carbonate components (discs cut from gorgonian axial skeletons, sections from the growing tips of Enallopsammia rostrata and Solenosmilia variabilis, and basal sections of Desmophyllum dianthus and Caryophyllia diomedeae), oven-dried overnight at $35^{\circ} \mathrm{C}$, on an Ohaus Explorer balance and determining their volumes by water displacement in a graduated cylinder appropriate in size for each specimen.

Table 1. Summary of ROV 'Jason' dive program. Site column refers to the name or number of the seamount, and Huon and TFZ refer, respectively, to the Huon and the Tasman Fracture Zone Marine Reserves

\begin{tabular}{|lclcrr|}
\hline Dive \# & Date (dd/mm/yy) & Site & Geographical coordinates & Depth (m) & Bottom time (h:min) \\
\hline 382 & $17 / 12 / 08$ & Hill A1, Huon & $44^{\circ} 20.24^{\prime} \mathrm{S}, 146^{\circ} 53.14^{\prime} \mathrm{E}$ & $1305-1689$ & $7: 20$ \\
383 & $18 / 12 / 08$ & Hill A1, Huon & $44^{\circ} 19.35^{\prime} \mathrm{S}, 147^{\circ} 15.85^{\prime} \mathrm{E}$ & $1291-1575$ & $12: 30$ \\
384 & $19 / 12 / 08$ & North Sisters Hill, Huon & $44^{\circ} 15.8^{\prime} \mathrm{S}, 147^{\circ} 14.24^{\prime} \mathrm{E}$ & $941-958$ & $10: 47$ \\
385 & $21 / 12 / 08$ & Hill Z27, Huon & $44^{\circ} 17.6^{\prime} \mathrm{S}, 147^{\circ} 38.0^{\prime} \mathrm{E}$ & $1061-1240$ & $10: 54$ \\
386 & $24 / 12 / 08$ & Mongrel, Huon & $44^{\circ} 15.03^{\prime} \mathrm{S}, 147^{\circ} 6.88^{\prime} \mathrm{E}$ & $729-1109$ & $17: 40$ \\
387 & $26 / 12 / 08$ & Hill Z39, Huon & $44^{\circ} 23.35^{\prime} \mathrm{S}, 147^{\circ} 16.38^{\prime} \mathrm{E}$ & $1439-2051$ & $48: 05$ \\
391 & $9 / 1 / 09$ & Outer wall, TFZ & $45^{\circ} 22.57^{\prime} \mathrm{S}, 144^{\circ} 34.44^{\prime} \mathrm{E}$ & $2386-4011$ & $16: 14$ \\
392 & $11 / 1 / 09$ & The 'Finger', TFZ & $45^{\circ} 17.75^{\prime} \mathrm{S}, 146^{\circ} 06.33^{\prime} \mathrm{E}$ & $2213-2898$ & $14: 50$ \\
393 & $12 / 1 / 09$ & The 'Knob', TFZ & $45^{\circ} 08.21^{\prime} \mathrm{S}, 146^{\circ} 58.66^{\prime} \mathrm{E}$ & $1410-1803$ & $14: 53$ \\
395 & $14 / 1 / 09$ & Hill K1, Huon & $44^{\circ} 18.02^{\prime} \mathrm{S}, 147^{\circ} 26.79^{\prime} \mathrm{E}$ & $1230-2194$ & $23: 58$ \\
\hline
\end{tabular}


The scleractinian sections were cut longitudinally before weighing and determination of volume, to expose inner septa and minimise air trapped inside the skeleton. The sizes of solitary scleractinians were quantified using maximum corallum width, measured using a digital micrometer (see Thresher et al. 2011b). The organic fraction of the bamboo corals was determined by dissolving sections of the internodes in $0.5 \mathrm{M}$ EDTA, pH adjusted to 8.0, at room temperature, filtering the residue onto pre-weighed filter paper, vacuum-drying the loaded filters for $24 \mathrm{~h}$, and then re-weighing the filter and samples on a Mettler Toledo micro-balance. Statistical analyses were done using Statview.

\section{RESULTS}

Carbonate saturation levels ( $\left.\Omega_{\text {aragonite }}\right)$ for the water column as a whole ranged from 2.39 (at $100 \mathrm{~m}$ depth) to 0.60 (at $3537 \mathrm{~m}$ ). Values close to the seamount substrata ranged from 1.24 to 0.61 . As expected, saturation levels correlate significantly with depth (Fig. 1). Comparison of total dissolved inorganic carbon dioxide and total alkalinity of the ambient seawater of the seamount samples with those taken from the shipbased hydrocasts show (1) carbonate depth profiles that are similar close to and off the seamounts; (2) a present-day ASH on the seamount at approximately $1050 \mathrm{~m}_{\text {; }}$ and (3) the CSH at just under $3200 \mathrm{~m}$ depth (Fig. 1). Variability in the ASH, as measured from 3 hydrocasts within 60 nautical miles of the sample sites, done in January 1994, September 1996 and October 2001, was between 1050 and $1190 \mathrm{~m}$ (CARINA Group 2010).

Taxa recorded, the maximum depths at which they were observed, and their primary skeletal mineralogy, if any, are given in Table 2. The maximum observed depths of cnidarians with aragonite skeletons (primarily scleractinians and hydrozoans), highmagnesium calcite (HMC) skeletons (primarily gorgonians), or little-or-no mineralised skeletons (primarily actiniarians, antipatharians and pennatulaceans) did not differ significantly (ANOVA: $F_{3,41}=$ 0.25, $\mathrm{p}=$ not significant [ns]) (Fig. 2). Peak development of the Solenosmilia variabilis reef, an aragonitic species, occurred at or slightly below the $\mathrm{ASH}$, but the solitary coral Desmophyllum dianthus, which also has an aragonite skeleton, dominated cliff-face assemblages to nearly $2400 \mathrm{~m}$. At this depth, seawater is ca. $20 \%$ under-saturated with respect to aragonite (Fig. 1). We also found dense stands of HMC isidid gorgonians (up to 5.6 colonies $\mathrm{m}^{-2}$ ) between 2100 and

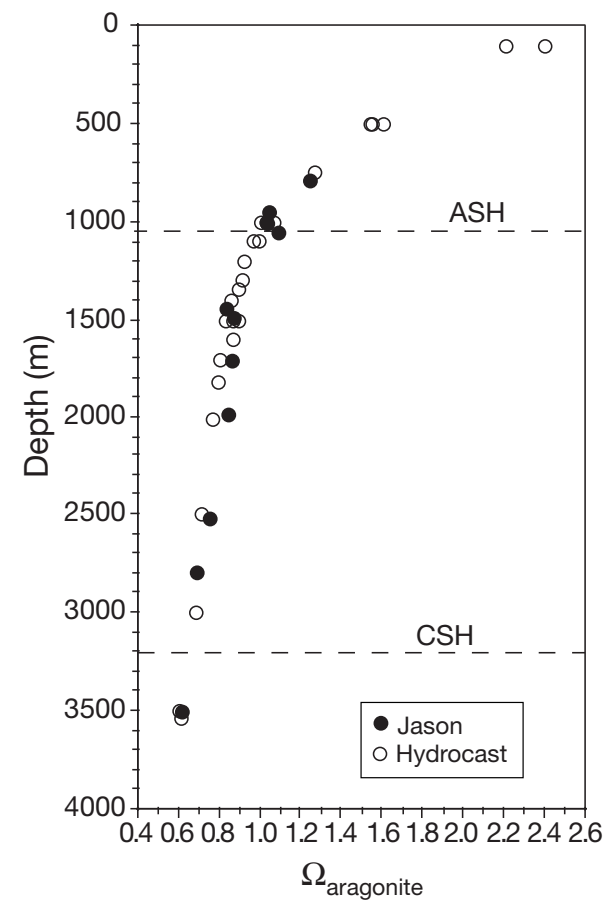

Fig. 1. Carbonate saturation level $\left(\Omega_{\text {aragonite }}\right)$ as a function of depth in the Tasmanian seamount environment, as assessed by ship-based hydrocasts and from samples taken using ROV 'Jason'. Sample locations span 3 hydrocasts and ROV 'Jason' samples from 9 different seamounts, all in the Huon Marine Reserve and Tasman Fracture Zones (see Table 1 for site details). Dashed lines indicate depths of the aragonite and calcite saturation horizons (ASH and $\mathrm{CSH}$, respectively)

$2600 \mathrm{~m}$ (see Thresher et al. 2011b). The solubility of HMC is similar to or slightly higher than that of aragonite (Morse et al. 2006), so that these stands were 1 to $1.5 \mathrm{~km}$ below the probable HMC saturation horizon. Among the deepest specimens observed were an isidid gorgonian (Lepidisis spp.) at $3945 \mathrm{~m}$, and a primnoid gorgonian, apparently Narella spp., at $3893 \mathrm{~m}$. The former had an internal skeleton of HMC $(8.9 \mathrm{~mol} \% \mathrm{Mg})$; the latter most likely had an aragonite axis (based on analysis of a congeneric specimen collected at $2559 \mathrm{~m}$ ). Both specimens, therefore, were growing in water that is nearly $40 \%$ under-saturated with respect to their primary mineral phase. Both, in fact, were growing in water that was under-saturated even with respect to pure calcite.

Skeletal composition also did not correlate with the maximum observed depth distributions of other taxa $\left(F_{5,27}=2.35, \mathrm{p}=0.07\right)$, though there is a tendency for those with calcite skeletons to be found at shallower depths than those with aragonite, HMC or no hard parts (Fig. 2). HMC echinoderms were common at depths $>4 \mathrm{~km}$ (ca. $45 \%$ under-saturated) and a gastropod (an apparent Mesoginella spp.), likely to have 
an aragonite shell, was photographed at $3912 \mathrm{~m}$ (ca. $40 \%$ under-saturated).

The anthozoan family for which we had livecaught specimens spanning the widest depth range

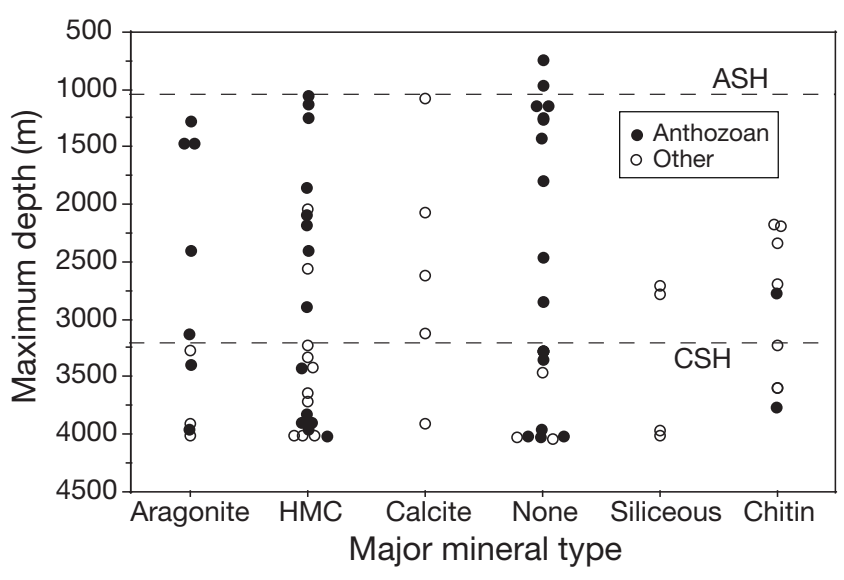

Fig. 2. Maximum depths of 78 taxa on Tasmanian seamounts, as recorded from images or samples taken using ROV 'Jason', split by primary skeletal mineralogy (see Table 3). The maximum depth sampled was $4011 \mathrm{~m}$. Dashed lines indicate the depths of the aragonite and calcite saturation horizons (ASH and $\mathrm{CSH}$, respectively). Differences in depth distributions among skeletal types are not significant for anthozoans or for all taxa sampled. HMC: highmagnesium calcite
(635 to $3945 \mathrm{~m}$ ) was the bamboo corals (Isididae; Gorgonacea). Isidid growth rates decline with $\Omega_{\text {arago- }}$ nite (estimated from Fig. 1, and assumed to be similar to the HMC saturation level, $\Omega_{\mathrm{HMC}}$ ) ( $\mathrm{r}=0.67, \mathrm{n}=12$, $\mathrm{p}=0.02$ ) (Fig. 3). The correlation is higher, however, with ambient temperature $(r=0.72, p=0.008)$, which also declines with depth. A direct effect of temperature on growth is consistent with a previously reported relationship for bamboo corals globally (Thresher 2009) and with poikilotherm physiology generally. Dry-weight skeletal density tended to increase, rather than decrease, with falling saturation levels (Fig. 3). The exception was the deepest specimen collected, which had a skeletal density about half that of other specimens. Overall, the correlation between skeletal density and saturation level is not significant $(r=0.02, n=36, p=n s)$, though it is significantly positive if the deepest specimen is excluded as an obvious outlier $(\mathrm{r}=0.43, \mathrm{p}=0.02)$. The contraintuitive result that skeletal density broadly increases with decreasing $\Omega_{\text {aragonite }}$ may reflect a relationship between growth rate and density. Among the specimens we examined, high skeletal growth rates correlated with lower skeletal density $(\mathrm{r}=0.76$, $\mathrm{n}=11, \mathrm{p}=0.006)$.

Within colonies, the relative amount of organic tissue in the isidid skeleton correlates with crystal type
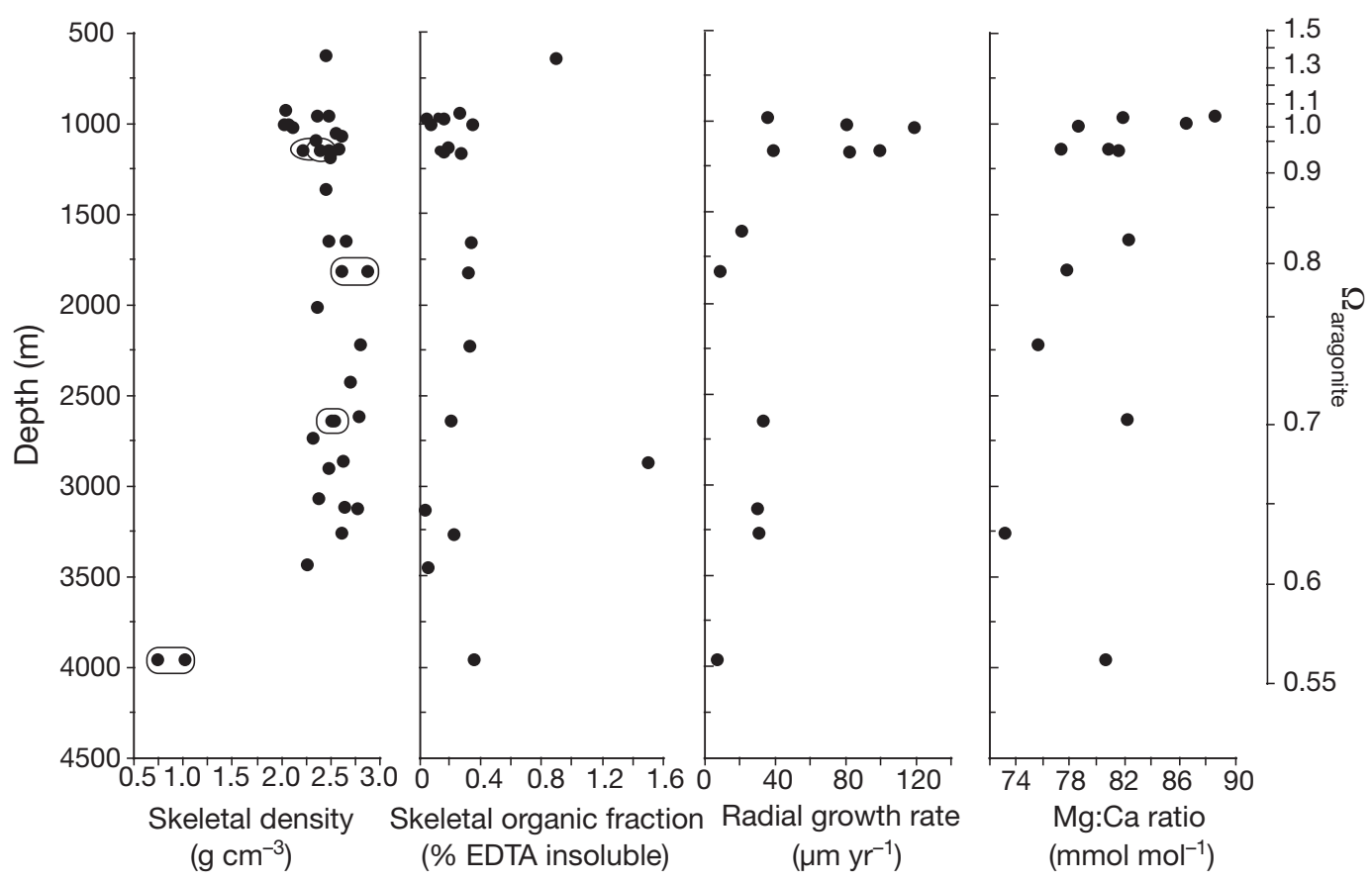

Fig. 3. Skeletal characteristics of live-collected specimens of the high-magnesium calcite (HMC) bamboo corals (Isididae; Gorgonacea) as a function of depth and carbonate saturation level ( $\Omega_{\text {aragonite }}$ ). Solubility of HMC is poorly defined, but at these $\mathrm{Mg} \mathrm{mol} \%$ it is likely to be similar to that of aragonite. Ovals in the skeletal density plot encircle replicate samples of the same coral, and provide an index of measurement error; the average difference between replicates was $145 \mathrm{mg} \mathrm{cm}-3$ 
Table 2. Maximum observed depths and skeletal mineralogy of seamount taxa. Generic identification for all but the shallowest material $(<1500 \mathrm{~m})$ is tentative, pending taxonomic analysis. HMC: high-magnesium calcite

\begin{tabular}{|c|c|c|c|}
\hline Species or taxon & Phylum, class and/or order & Major mineral type & Max. observed depth (m) \\
\hline Demospongia spp. & Porifera & Siliceous & 3970 \\
\hline Hexactinellid sp. 1 (bowl-shaped) & Porifera & Siliceous & 2782 \\
\hline Hexactinellid sp. 2 (tulip-shaped) & Porifera & Siliceous & 2709 \\
\hline Hexactinellid sp. 3 (vase-shaped) & Porifera & Siliceous & 2709 \\
\hline Actinernus elongatus & Actiniaria & None & 1438 \\
\hline Hormathiid anemone & Actiniaria & None & 3271 \\
\hline Cerianthid anemone & Actiniaria & None & 4008 \\
\hline Actinoscyphiid anemone & Actiniaria & None & 2450 \\
\hline Actinaria sp. 1 & Actiniaria & None & 1236 \\
\hline Actinaria sp. 2 & Actiniaria & None & 1251 \\
\hline Actinaria sp. 3 & Actiniaria & None & 1130 \\
\hline Actinaria sp. 4 & Actiniaria & None & 3335 \\
\hline Actinaria sp. 5 & Actiniaria & None & 3335 \\
\hline Actinaria sp. 6 & Actiniaria & None & 3271 \\
\hline Actinaria sp. 7 & Actiniaria & None & 3271 \\
\hline Actinaria sp. 8 & Actiniaria & None & 958 \\
\hline Actinaria sp. 9 & Actiniaria & None & 1130 \\
\hline Actinaria sp. 10 & Actiniaria & None & 3892 \\
\hline Anthomastus spp. & Alcyonacea & None & 2841 \\
\hline Leiopathes spp. & Antipatharia & Chitin & 3752 \\
\hline Black coral spp. (branching) & Antipatharia & Chitin & 2706 \\
\hline Corallium spp. (small white) & Coralliidae; Gorgonacea & HMC & 3401 \\
\hline Corallium spp. (large pink) & Coralliidae; Gorgonacea & HMC & 2173 \\
\hline Anthothela spp. & Paragorgiidae; Gorgonacea & $\mathrm{HMC}$ & 1060 \\
\hline Paragorgia spp. & Paragorgiidae; Gorgonacea & HMC & 2082 \\
\hline Chrysogorgia spp. & Chrysogorgiidae; Gorgonacea & HMC & 2800 \\
\hline Pleurogorgia spp. & Chrysogorgiidae; Gorgonacea & HMC & 1123 \\
\hline Isidella spp. & Isididae; Gorgonacea & HMC & 3892 \\
\hline Keratoisis spp. (large, branching) & Isididae; Gorgonacea & HMC & 1050 \\
\hline Keratoisis spp. (fine branching) & Isididae; Gorgonacea & HMC & 3780 \\
\hline Lepidisis spp. & Isididae; Gorgonacea & HMC & 3945 \\
\hline Narella spp. & Primnoidae; Gorgonacea & Aragonite & 3893 \\
\hline Parastenella spp. & Primnoidae; Gorgonacea & $\mathrm{HMC}^{\mathrm{a}}$ & 2395 \\
\hline Primnoisis spp. & Primnoidae; Gorgonacea & $\mathrm{HMC}$ & 1846 \\
\hline Thouarella spp. & Primnoidae; Gorgonacea & $\mathrm{HMC}$ & 2395 \\
\hline Tokoprymno spp. & Primnoidae; Gorgonacea & $\mathrm{HMC}^{\mathrm{a}}$ & 1846 \\
\hline Stylaster spp. & Stylasteridae; Anthoathecata & Aragonite & 3145 \\
\hline Lepidotheca spp. (cf. L. chauliostylus) & Stylasteridae; Anthoathecata & Aragonite ${ }^{a}$ & 3398 \\
\hline Calibelemnon spp. & Chunellidae; Pennatulacea & None & 1782 \\
\hline Pennatulacea spp. & Pennatulidae; Pennatulacea & None & 4009 \\
\hline Umbellula spp. & Umbellulidae; Pennatulacea & None & 4009 \\
\hline Caryophyllia diomedeae & Caryophylliidae; Scleractinia & Aragonite & 1460 \\
\hline Desmophyllum dianthus & Caryophylliidae; Scleractinia & Aragonite & 2395 \\
\hline Solenosmilia variabilis & Caryophylliidae; Scleractinia & Aragonite & 1460 \\
\hline Enallopsammia rostrata & Dendrophylliidae; Scleractinia & Aragonite & 1266 \\
\hline Zoanthiniaria spp. & Zoanthidea & None & 3271 \\
\hline Serpulid spp. & Polychaeta & Aragonite & 4002 \\
\hline Sabellid spp. & Polychaeta & Aragonite & 3271 \\
\hline Jaffaia jaffaensis & Brachiopoda & Calcite & 2066 \\
\hline Delectopecten spp. & Bivalvia & Calcite & 1080 \\
\hline Mesoginella spp. & Gastropoda & Aragonite $^{\mathrm{a}}$ & 3912 \\
\hline Arcturid spp. & Decapoda & Chitin & 3589 \\
\hline Brachyuran spp. & Decapoda & Chitin & 2338 \\
\hline Lithodid spp. & Decapoda & Chitin & 2688 \\
\hline Munida isos & Decapoda & Chitin & 2193 \\
\hline Pagurid spp. & Decapoda & Chitin & 2170 \\
\hline Nematocarcinid spp. & Decapoda & Chitin & 3591 \\
\hline
\end{tabular}


Table 2 (continued)

\begin{tabular}{|c|c|c|c|}
\hline Species or taxon & Phylum, class and/or order & Major mineral type & Max. observed depth (m) \\
\hline Bathypallenopsis spp. & Pantopoda & Chitin & 3231 \\
\hline Bathylasmatid spp. & Tetraclitoidea & Calcite $^{\mathrm{a}}$ & 3909 \\
\hline Tetrachaelasma tasmanica & Tetraclitoidea & Calcite & 3617 \\
\hline Brisingoid & Asteroidea & $\mathrm{HMC}^{\mathrm{a}}$ & 3409 \\
\hline Smilasterias spp. & Asteroidea & $\mathrm{HMC}^{\mathrm{a}}$ & 2733 \\
\hline Solasterid spp. & Asteroidea & $\mathrm{HMC}^{\mathrm{a}}$ & 3232 \\
\hline Phrynocrinus nudus & Crinoidea & $\mathrm{HMC}^{\mathrm{a}}$ & 4009 \\
\hline Comatulid spp. & Crinoidea & $\mathrm{HMC}^{\mathrm{a}}$ & 3720 \\
\hline Dermechinus horridus & Echinoidea & $\mathrm{HMC}^{\mathrm{a}}$ & 2040 \\
\hline Echinothuriid spp. & Echinoidea & Calcite $^{\mathrm{a}}$ & 3128 \\
\hline Histocidaris spp. & Echinoidea & $\mathrm{HMC}^{\mathrm{a}}$ & 4011 \\
\hline Holothurian sp. 1 (large black) & Holothuroidea & $\mathrm{HMC}$ & 4010 \\
\hline Holothurian sp. 2 (transparent) & Holothuroidea & HMC & 3640 \\
\hline Bathypectinura spp. & Ophiuroidea & $\mathrm{HMC}^{\mathrm{a}}$ & 4010 \\
\hline Ophiocanthid spp. & Ophiuroidea & $\mathrm{HMC}$ & 2560 \\
\hline Octacnemid spp. & Ascidacea & None & 4009 \\
\hline Ascidean spp. & Ascidacea & None & 4005 \\
\hline Enteropneust (large) spp. & Hemichordata & None & 3445 \\
\hline
\end{tabular}

and growth rate (Noe \& Dullo 2006). In our samples, skeletal organic fraction did not correlate with $\Omega_{\text {aragonite }}(\mathrm{r}=0.01, \mathrm{n}=20, \mathrm{p}=\mathrm{ns}$ ) (Fig. 3), even after excluding 2 outliers. Mean $\mathrm{Mg}: \mathrm{Ca}$ ratios tended to be lower at low saturation levels $(\mathrm{r}=0.52, \mathrm{n}=13, \mathrm{p}<$ $0.07)$, but as with growth rate, the correlation is better against temperature $(\mathrm{p}=0.05)$ (Thresher et al. 2010). The total range of mean $\mathrm{Mg}: \mathrm{Ca}$ ratios among our specimens was small (7.31 to $8.86 \mathrm{~mol} \%$ ) (Table 3), despite large differences in carbonate concentrations.

Results for other taxa are similar. Skeletal density does not correlate with carbonate ion concentration for live-caught specimens of the aragonitic scleractinians Caryophyllia diomedeae and Desmophyllum dianthus (both species pooled: $\mathrm{r}=0.01, \mathrm{n}=38, \mathrm{p}=\mathrm{ns}$, $\Omega_{\text {aragonite: }} 1.07$ to 0.69 ) (Fig. 4), Solenosmilia variabilis $\left(\mathrm{r}=0.10, \mathrm{n}=13, \mathrm{p}=\mathrm{ns}, \Omega_{\text {aragonite: }} 1.1\right.$ to 0.83$)$, or Enallopsammia rostrata $\left(\mathrm{r}=0.50, \mathrm{p}=\mathrm{ns}, \mathrm{n}=6\right.$, $\Omega_{\text {aragonite: }}$ 1.08 to 0.93 ). Sample sizes were small, but we also saw no depth effect on skeletal density in 2 other HMC gorgonian genera (Corallium spp.: $\mathrm{r}=0.08, \mathrm{n}=$ 5, p = ns, depth 1061 to 2173 m; Paragorgia spp.: $\mathrm{r}=$ $0.18, \mathrm{n}=7, \mathrm{p}=\mathrm{ns}$, depth 982 to $2082 \mathrm{~m})$. Specimen size did not correlate with depth in $D$. dianthus $(\mathrm{r}=0.03$, $\mathrm{p}=\mathrm{ns}, \mathrm{n}=269$, depth range 1295 to $2395 \mathrm{~m}$ ) (Fig. 4), a relationship we speculated might hold if there was a high physiological cost (i.e. slower growth rate and smaller maximum size) of calcifying at low saturation levels. Finally, Mg:Ca ratios for all 20 calcitic taxa that we measured were unrelated to the taxa's maximum observed depth $(\mathrm{r}=0.13, \mathrm{p}=\mathrm{ns})$. Among specimens, $\mathrm{Mg}$ :Ca ratios ranged from 0.8 to $20.9 \mathrm{~mol} \%$.
Anomalies in the deepest coral we collected, Lepidisis (L16), suggest that $40 \%$ under-saturation is close to the limit at which bamboo corals (Isididae; Gorgonacea) can grow. The skeletal density of this specimen was half that of shallower specimens (Fig. 3), its radial growth rate was the lowest we measured and about $70 \%$ less than predicted based on ambient temperature (Thresher 2009), and both its inner structure and outer margin showed evidence of apparent erosion and re-growth (Fig. 5). The ${ }^{14} \mathrm{C}$ data indicate L16 to be ca. $290 \mathrm{yr}$ old, indicating that despite the apparently adverse conditions, it has been able to persist over the long term.

Indications of an effect of $\Omega_{\text {aragonite }}$ of reef accumulation differed between taxa. In the bamboo corals, sub-fossils collected at depths $<1000 \mathrm{~m}$ were abundant, solid and appeared old. Their organic nodes were eroded and their HMC internodes were extensively bored. ${ }^{14} \mathrm{C}$ dating confirmed that some specimens were more $>1000$ yr old. In contrast, sub-fossil material collected deeper than ca. $2300 \mathrm{~m}$ appeared to be of recent origin, with organic nodes still intact and the carbonate internodes un-bored. These deeper sub-fossils were uncommon relative to the dense stands of live colonies present, and consisted of skeletal material that was soft and crumbled when touched, i.e. apparently dissolving. We were unable to find what appeared to be older material at these depths despite digging in sediment/rubble banks. In contrast, sub-fossil scleractinians were abundant well below the ASH. We collected nearly 2500 essentially intact Desmophyllum dianthus sub-fossils at 
Table 3. Mineralogy of samples collected on Tasmanian seamounts, as determined using X-ray diffraction (XRD). Mg:Ca and $\mathrm{Sr}$ :Ca ratios were subsequently determined using X-ray fluorescence (XRF) or, for a few small samples, wavelength dispersive electron probe microanalysis (WD-EPMA). Wherever possible (most anthozoan taxa), we analysed a specimen taken close to the maximum depth at which each taxon was observed, to take into account possible changes in skeletal composition with increasing depth. Max. depth: maximum depth observed (m). nd: not detected

\begin{tabular}{|c|c|c|c|c|c|c|c|}
\hline \multirow{2}{*}{ Species } & \multirow{2}{*}{ Group } & \multirow{2}{*}{$\begin{array}{c}\text { Sample } \\
\text { depth } \\
\text { (m) }\end{array}$} & \multirow{2}{*}{$\begin{array}{l}\text { Max. } \\
\text { depth } \\
(\mathrm{m})\end{array}$} & \multicolumn{2}{|c|}{ Mineral type(s) } & \multirow{2}{*}{$\begin{array}{c}\mathrm{Mg}: \mathrm{Ca} \\
(\mathrm{mmol}) \\
\mathrm{mol}^{-1}\end{array}$} & \multirow{2}{*}{$\begin{array}{l}\mathrm{Sr}: \mathrm{Ca} \\
\left(\mathrm{mmol}^{-1}\right. \\
\left.\mathrm{mol}^{-1}\right)\end{array}$} \\
\hline & & & & Major & Minor & & \\
\hline Corallium sp. 1 & Coralliidae; Gorgonacea & 2173 & 2173 & Mg calcite & Trace aragonite & 103.96 & 2.47 \\
\hline Corallium sp. 2 & Coralliidae; Gorgonacea & 1864 & 3401 & Mg calcite & nd & 104.12 & 2.56 \\
\hline Anthothela spp. & Paragorgiidae; Gorgonacea & 1060 & 1060 & Mg calcite & nd & 102.19 & 2.05 \\
\hline Paragorgia sp. 1. & Paragorgiidae; Gorgonacea & 1893 & 1893 & Mg calcite & Halite & 137.45 & 2.55 \\
\hline Paragorgia sp. 2 & Paragorgiidae; Gorgonacea & $\sim 1000$ & 1000 & Mg calcite & Halite & 151.85 & 2.68 \\
\hline Chrysogorgia spp. & Chrysogorgiidae; Gorgonacea & 1060 & 2800 & Mg calcite & Aragonite & 188.73 & 2.13 \\
\hline Isidella spp. & Isididae; Gorgonacea & 3434 & 3892 & Mg calcite & nd & 109.23 & 2.51 \\
\hline Keratoisis spp. & Isididae; Gorgonacea & $\sim 1000$ & 1050 & Mg calcite & nd & 85.84 & 3.17 \\
\hline Lepidisis spp. & Isididae; Gorgonacea & 3256 & 3945 & Mg calcite & nd & 99.92 & 2.46 \\
\hline Narella spp. (spicules) & Primnoidae; Gorgonacea & 1080 & 2559 & Mg calcite & $\begin{array}{l}\text { Halite, possible } \\
\text { trace quartz }\end{array}$ & 104.72 & 1.98 \\
\hline Narella spp. (axis) & Primnoidae; Gorgonacea & 1080 & 2559 & Aragonite & Calcite & 6.17 & 8.30 \\
\hline Primnoisis spp. & Primnoidae; Gorgonacea & 1060 & 1846 & Mg calcite & Aragonite & 125.28 & 2.98 \\
\hline Thouarella spp. (spicules) & Primnoidae; Gorgonacea & $\sim 1000$ & 2395 & Mg calcite & Aragonite & 83.54 & 3.86 \\
\hline Black coral & Antipatheria & 2243 & 3752 & nd & Aragonite, Calcite & 209.77 & 7.76 \\
\hline Caryophyllia diomedeae & Caryophylliidae; Scleractinia & 1460 & 1460 & Aragonite & Possible trace calcite & 3.43 & 8.45 \\
\hline Desmophyllum dianthus & Caryophylliidae; Scleractinia & 2395 & 2395 & Aragonite & Possible trace $\mathrm{Mg}$ calcite & e 2.47 & 8.57 \\
\hline Solenosmilia variabilis & Caryophylliidae; Scleractinia & 1430 & 1430 & Aragonite & $\begin{array}{l}\text { Halite, possible } \\
\text { trace calcite }\end{array}$ & 5.02 & 9.05 \\
\hline Enallopsammia rostrata & Dendrophylliidae; Scleractinia & 1266 & 1266 & Aragonite & $\begin{array}{c}\text { Possible trace calcite } \\
\text { and halite }\end{array}$ & 4.09 & 9.59 \\
\hline Stylaster sp. 1 & Anthoathecata & 1680 & 2069 & Aragonite & Trace Mg calcite & 5.156 & 9.28 \\
\hline Stylaster sp. 2 & Anthoathecata & $\sim 1000$ & 3398 & Aragonite & nd & 3.50 & 9.18 \\
\hline Sabellid sp. 1 & Polychaeta & 1050 & 4002 & Mg calcite & $\begin{array}{c}\text { Halite, possible trace } \\
\text { quartz }\end{array}$ & 94.10 & 2.89 \\
\hline Sabellid sp. 2 & Polychaeta & 1050 & 4002 & $\begin{array}{c}\text { Aragonite, } \\
\text { calcite }\end{array}$ & $\begin{array}{l}\text { Trace quartz } \\
\text { and gypsum }\end{array}$ & 9.22 & 6.21 \\
\hline Gracilechinus multidentatus & Echinodermata & $\sim 1000$ & 1000 & Calcite & Possible trace quartz & 29.10 & 1.64 \\
\hline Jaffara jaffaenis & Brachiopoda & 1080 & 2086 & Calcite & $\begin{array}{l}\text { Halite, possible } \\
\text { trace aragonite }\end{array}$ & 11.29 & 0.70 \\
\hline Fusitriton magellanicus & Gastropoda & 2170 & 3912 & Aragonite & Possible trace Mg calcite & e $\quad 0.00$ & 1.19 \\
\hline Delectopecten spp. & Bivalvia & 1080 & 1080 & Calcite & $\begin{array}{l}\text { Halite, Aragonite, } \\
\text { trace gypsum }\end{array}$ & 28.33 & 1.93 \\
\hline Tetrachaelasma tasmanicum & Tetraclitoidea & 2225 & 2617 & Calcite & nd & 21.68 & 2.78 \\
\hline Crinoid spp. & Crinoidea; Echinodermata & 1680 & 4009 & Mg calcite & $\begin{array}{c}\text { Halite, possible trace } \\
\text { quartz }\end{array}$ & 136.54 & 2.10 \\
\hline Phormosoma spp. & Crinoidea; Echinodermata & 1448 & 4009 & Calcite & Possible trace quartz & 39.55 & 1.51 \\
\hline Gracilechinus multidentatus & Echinoidea; Echinodermata & $\sim 1000$ & 1000 & Calcite & Possible trace quartz & 29.10 & 1.64 \\
\hline Ophicreas sibogae & Ophiuroidea; Echinodermata & $\sim 1000$ & 2560 & Mg calcite & nd & 160.56 & 1.71 \\
\hline
\end{tabular}

depths below $2000 \mathrm{~m}$, i.e. approximately $1 \mathrm{~km}$ below the ASH. ${ }^{14} \mathrm{C}$ analysis dates some of this material to the Last Glacial Maximum (Thresher et al. 2011b). On most seamounts, we also found extensive, largely intact but also largely dead Solenosmilia variabilis reefs present to depths of about $1600 \mathrm{~m}$, ca. $0.5 \mathrm{~km}$ below the ASH. This material was extensively coated with a ferro-manganese oxide crust. The only specimen from these depths we have dated thus far was approximately $11100 \mathrm{yr}$ old (N. Thiagarajan pers. comm.).

\section{DISCUSSION}

Declining ocean carbonate concentrations have been suggested to have diverse ecological and physiological impacts on marine organisms, including affecting their sensory capabilities and behaviour (Bibby et al. 2007, Munday et al. 2009), reproduction (Havenhand et al. 2008, Ellis et al. 2009) and, directly, their ability to form carbonate skeletons (Langdon \& Atkinson 2005, Cohen et al. 2009, Moy et al. 2009). Data to support these suggestions are 


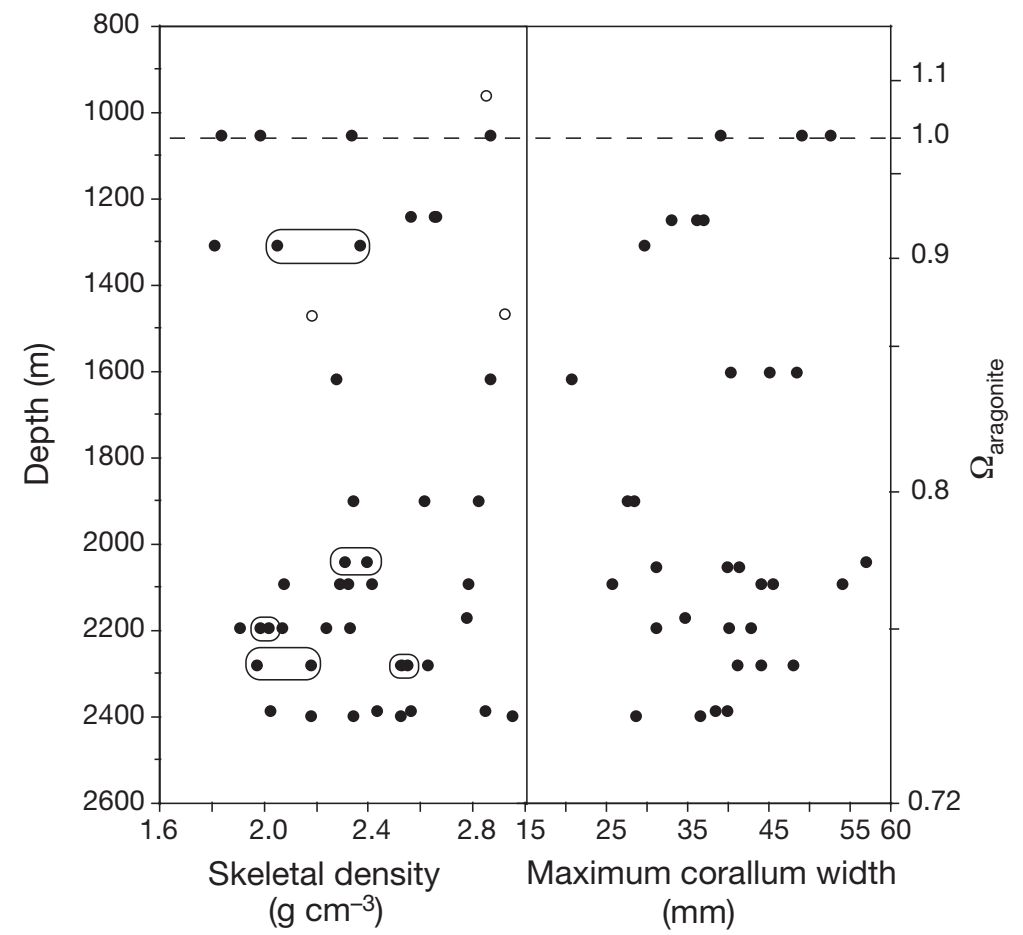

Fig. 4. Desmophyllum dianthus and Caryophyllia diomedeae. Skeletal density and size of live-collected specimens of the aragonitic solitary scleractinian $D$. dianthus (๑), as a function of depth and aragonite saturation level $\left(\Omega_{\text {aragonite}}\right)$. Horizontal dashed line indicates depth of the aragonite saturation horizon (ASH). The maximum depth at which live $D$. dianthus was seen was $2395 \mathrm{~m}$. Data for C. diomedeae (O) are included for comparative purposes. Ovals in the skeletal density plot encircle replicate samples of the same coral, and provide an index of measurement error; the average difference between replicates was $187 \mathrm{mg} \mathrm{cm}^{-3}$.

Correlations against depth are not significant for either variable

based primarily on short-term exposure of organisms to low carbonate concentrations in the laboratory. Alternative approaches include examining historical samples at sites where $\Omega_{\text {aragonite }}$ have demonstrably changed over recent decades, e.g. declining foraminiferan shell weights in the Southern Ocean (Moy et al. 2009), and the distribution and characteristics of taxa along natural carbonate concentration gradients (Hall-Spencer et al. 2008). We used the latter approach, by examining in detail the depth distribution and life-history characteristics of corals and other shell-forming megabenthos along the slopes of deepsea seamounts and associated structure in the SW Pacific. The gradient of water chemistry spanned by the present study ranged from super-saturated with respect to aragonite and $\mathrm{HMC}$ to under-saturated even with respect to calcite. This gradient provided an opportunity to assess the responses of deep-sea taxa, including corals, on evolutionary and ecological time scales to the effects of chronic low carbonate concentrations.
We found little evidence that carbonate under-saturation to at least $-30 \%$ affected the distribution, skeletal composition, or growth rates of corals and other megabenthos on Tasmanian seamounts. Both solitary scleractinian corals and colonial gorgonians were abundant at depths well below their respective saturation horizons and appeared healthy. HMC echinoderms were common as deep as we sampled $(4011 \mathrm{~m})$, in water that was ca. $45 \%$ undersaturated. For both anthozoan and nonanthozoan taxa, there was no obvious difference in species' maximum observed depths as a function of skeletal mineralogy, i.e. the community was not obviously shifted towards taxa with either less soluble or no skeletal structure at increasing depth. With the possible exception of the 2 bioherm-forming scleractinians, Solenosmilia variabilis and Enallopsammia rostrata, both of which were found above or close to the ASH, it is not obvious from our data that carbonate saturation state and skeletal mineralogy have any effect on species' depth distributions to the maximum depth we sampled (4011 m). With the exception of the deepest bamboo coral we collected, we also saw little evidence of an effect of carbonate under-saturation on growth rates and skeletal features. Depthcorrelated changes in $\mathrm{Mg}: \mathrm{Ca}$ ratios and growth rates of bamboo corals could relate to falling carbonate levels, but are more parsimoniously attributed to stoichiometric and physiological effects of temperatures that decline with increasing depth. The skeletal morphology of L16 suggests that this tolerance of low carbonate concentrations has a limit, however, in the case of isidids at about $40 \%$ undersaturated. For conditions above that, the physiology of the coral appears able to cope with whatever costs or stresses are associated with skeletal accretion in a very low-carbonate environment. These data suggest a threshold carbonate level below which the isidids could no longer sustain 'normal' skeletal structure, composition and growth rate, which is consistent with laboratory evidence of a non-linear response by corals to ocean acidification (Holcomb et al. 2010, Ries et al. 2010).

The observation that the distributions of deep-sea corals are not constrained by carbonate levels below saturation is broadly supported by the literature. Solitary scleractinians have been reported as deep as 


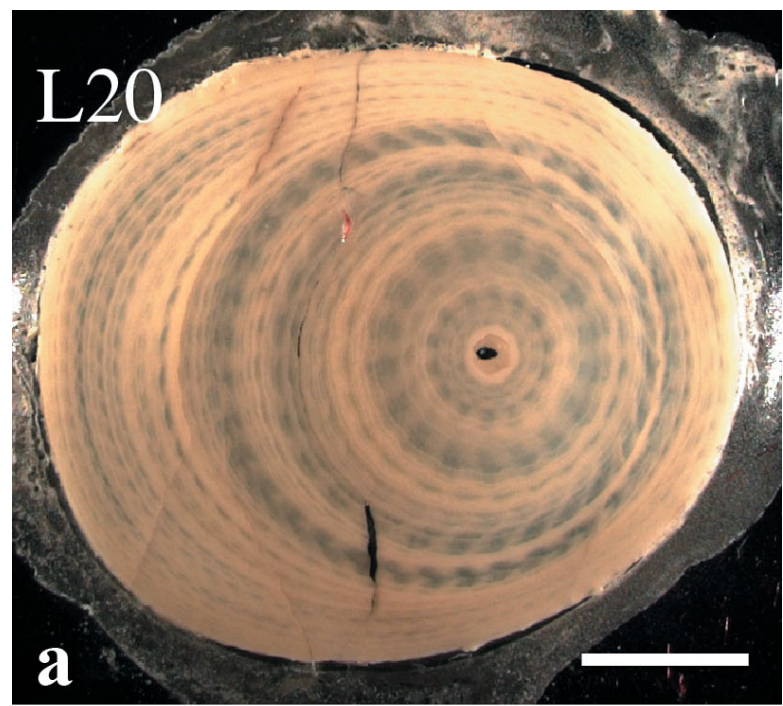

$6 \mathrm{~km}$ (Fautin at el. 2009) and isidid gorgonians as deep as $4 \mathrm{~km}$ (Roark et al. 2005), both reports well below the aragonite and HMC saturation horizons, respectively. Fautin et al. (2009) report that corallimorpharians, a non-skeleton-forming sister group to the scleractinians, tend to be found deeper in the Challenger deep-sea surveys than solitary Scleractinia, which they suggest is a response to very low saturation states in the deep ocean. However, they did not find a similar difference between corallimorpharians and solitary scleractinians in a set of Antarctic surveys, and noted that their observations need to be confirmed by wider sampling. It is certainly plausible that the metabolic costs of calcifying in extremely low-carbonate environments are prohibitive, but our data provide no indication that conditions below saturation per se dictate any overall shifts in community composition, again with the possible exception of the bioherm-forming scleractinians.

Two factors have been suggested that might facilitate tolerance of low-carbonate conditions by deepsea benthos. First, the skeleton of these organisms is probably not normally directly exposed to lowcarbonate seawater for extended periods. As recently highlighted by Cohen \& Holcomb (2009), one or more cell membranes (the scleractinian calicoblastic layer and isidid coenenchyme) envelope the skeleton of live corals when the latter are fully expanded. This tissue layer largely or completely isolates the calcification process and chemistry from seawater (McConnaughey 1989, Adkins et al. 2003, Cohen \& McConnaughey 2003) and presumably the skeleton itself from the threat of low carbonate dissolution. In that regard, predation and carbonate chemistry may jointly constrain populations of anthozoans below the saturation horizon. We frequently observed seastars wrapped around and apparently feeding on bamboo corals at depths in excess of $2 \mathrm{~km}$, often in association with bare white patches of exposed skeleton that looked to have been recently stripped of live tissue (Fig. 6). We suspect that growth at these depths, and the skeletal morphology of L16, consists of episodes of predation, skeletal erosion and re-growth as the coenenchyme re-expands to cover and protect the

Fig. 5. Lepidisis spp. Cross-sections of specimens from (a) $1645 \mathrm{~m}$ (L20), (b) $3256 \mathrm{~m}$ (L19) and (c) $3945 \mathrm{~m}$ (L16). By comparison with the shallower specimens, the skeleton of L16, which was the deepest specimen we collected, lacks the banded internal growth structure typical of the genus, includes prominent organic inclusions (brown spots in the upper right of panel c), strongly suggestive of dissolution and re-growth (see Noe \& Dullo 2006), and has an irregular and apparently eroded outer surface. Scale bars $=3 \mathrm{~mm}$ 


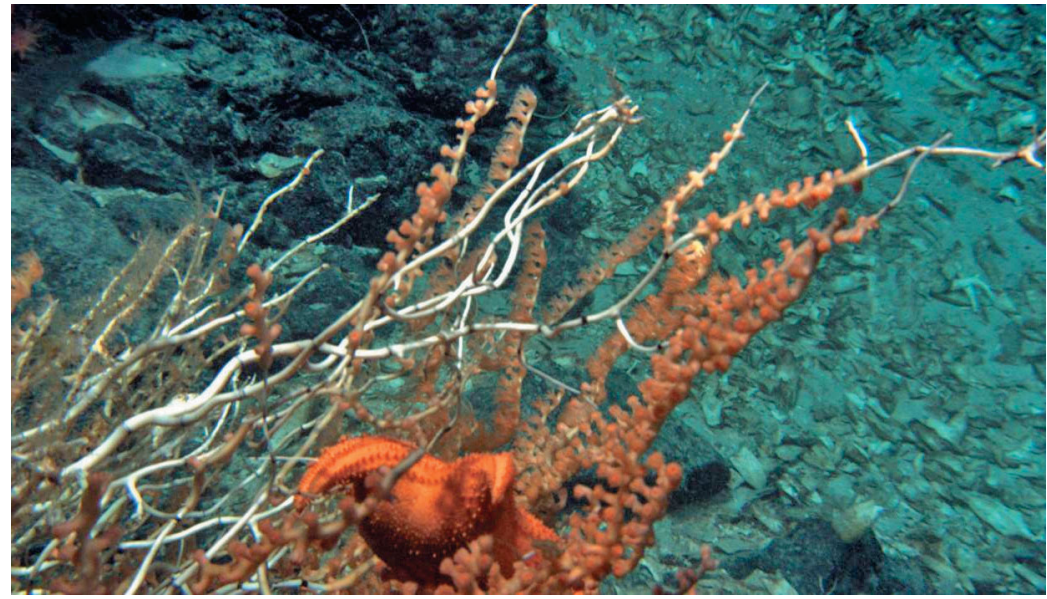

Fig. 6. A seastar apparently feeding on bamboo coral Keratoisis spp. at $2540 \mathrm{~m}$ depth on a seamount just outside the Tasman Fracture Zone Marine Reserve. Note both the exposed white high-magnesium calcite (HMC) skeleton, presumably the result of seastar predation on the polyps, and the different polyp densities, which we speculate reflects coral regrowth over exposed skeleton. Image copyright:Woods Hole Advanced Imaging and Visualization Laboratory

exposed HMC. Acidification could shift the balance of this predator-prey dynamic, by increasing rates of erosion and weakening colony structure prior to regrowth.

The second factor that has been identified as important in buffering the effects of low carbonate levels on skeletal accretion is food availability. Physiological studies of shallow-water taxa suggest (1) that calcification is energetically expensive, consuming up to $30 \%$ of the coral's available resources, and (2) that normal calcification rates can be sustained in relatively low-carbonate environments ( $\Omega_{\text {aragonite }}$ ca. 1.5 to 2.0 ) under elevated feeding or nutrient regimes (reviewed by Cohen \& Holcomb 2009). Although saturation levels in those studies are considerably higher than those experienced by the deep-sea taxa we observed, the principle that elevated food availability could compensate for the higher costs of calcification in heterotrophic deepsea species appears plausible. Radiocarbon and ${ }^{15} \mathrm{~N}$ studies show that to depths of at least $1000 \mathrm{~m}$, bamboo corals consume sinking particulate organic carbon (Sherwood et al. 2009). A similar food source has been speculated for other deep-water corals (Roberts et al. 2009). The hypothesis that this carbon source is sufficiently abundant to compensate for increased costs of calcification appears at odds with a general observation that deep-sea communities are typically sparse and food-limited (recently reviewed by Rex et al. 2006). Three observations, however, are locally consistent with the hypothesis. First, the Tasmanian seamounts are located close to the transition between the subtropical convergence and subantarctic front, an area of high productivity and carbon export to the deep ocean (Clementson et al. 1998). Second, although no specific work has been done on the Tasmanian seamount region, several hypotheses have been proposed regarding seamount-specific circulation features (e.g. Taylor columns) that could concentrate local primary and secondary production and facilitate the development of extensive deep-sea megabenthic communities (White et al. 2007). Third, biomass density of megabenthos below $2000 \mathrm{~m}$ in the Tasmanian seamount region is exceptionally high by global standards (Thresher et al. 2011a). The production that supports this dense community is not yet clear, but the dense biomass suggest high levels of food availability in the deep seamount environment.

Whatever the proximate causes, our data suggest that a change in carbonate saturation horizons per se as a result of ocean acidification is likely to have only a slight effect on most of the live deep-sea biogenic calcifiers in our study area. The 2 relatively shallow-water reef-forming scleractinians, Solenosmilia variabilis and Enallopsammia rostrata, may be an exception. Their distributions in our study area are consistent with reports that globally the maximum depths of $>95 \%$ of bioherm-forming coldwater scleractinians coincide approximately with the ASH (Guinotte et al. 2006). This consistency implies that $\Omega_{\text {aragonite }}$ constrain the distributions of the colonial taxa. Why these colonial scleractinians are limited to water saturated or near-saturated with carbonates, whereas the solitary species are not, is not clear. Possibly the elongate, branching skeletons characteristic of bioherm-forming taxa are less well protected by live tissue than the more compact skeletons of the solitary species. Maier et al. (2009) noted that the growth rates of fast-growing tips of the relatively shallow-water reef-forming coral Lophelia pertusa were more sensitive to acidification than slower-growing parts of the colony. Possibly bioherm-forming deep-sea corals typically grow more quickly than solitary species, and hence are more sensitive to changing carbonate concentrations. Alternatively, the chemistry and physiology of building a complex, branching linear skeleton of 
aragonite may be inherently sensitive to $\Omega_{\text {aragonite }}$ although we saw no obvious effect of up to $17 \%$ under-saturation on the skeletal density of $S$. variabilis. The latter could be in part explained by an averaging effect of natural or anthropogenic variability in the depth of the ASH. However, our deepest samples of $S$. variabilis, from $1454 \mathrm{~m}$, were taken well below either the deepest report locally of the ASH (1190 m; CARINA Group 2010) or estimates of recent shoaling due to anthropogenic $\mathrm{CO}_{2}$ emissions (ca. $150 \mathrm{~m} ;$ R. Matear pers. comm.).

If direct impacts of falling carbonate levels on live deep-sea corals are relatively slight, except possibly for the bioherm-forming scleractinians, impacts on the rate at which coral skeletal material accumulates into structure-forming reefs (Guinotte \& Fabry 2008) are also ambiguous. On the one hand, we found evidence of dissolution of HMC gorgonian skeletons at depths below the likely HMC saturation horizon, with little or no accumulation of reefal material. It is likely that ocean acidification will increase the dissolution rate of this skeletal material, and hence result in some shoaling and loss of HMC bioherms. In contrast, sub-fossil scleractinian skeletons were very

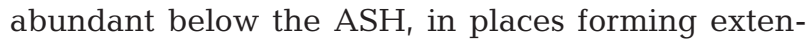
sive reefs. We speculate that the contrast between persistence of the scleractinian and dissolution of the bamboo coral sub-fossils reflects in part a dissolution rate that accelerates non-linearly with increasing under-saturation, and in part an effect of ferro-manganese deposits on the solubility of scleractinian skeletons (see Hein et al. 2010). The dead Solenosmilia variabilis reef below $1400 \mathrm{~m}$, though extensive, is almost entirely black from the metal oxide coating. We also noted, however, that this dead reef is biologically depauperate (Thresher unpubl. data), suggesting that even if the coating conserves the reef matrix, it is not a preferred substratum for benthic organisms.

Acknowledgements. We thank E. Anagnostou, A. Beck, W. Cho, A. Gagnon, K. Gowlett-Holmes, S. John, A. Kennedy, H. Kippo, N. Meckler, D. Mills, D. Staples, A. Subhas and N. Thiagarajan; the crews of the autonomous underwater vehicle (AUV) 'ABE', the ROV 'Jason' and the RVs 'Thomas T. Thompson' and 'Southern Surveyor' for their professional assistance in the field; P. Alderslade, S. Cairns, D. Fautin, K. Gowlett-Holmes, F. McEnnulty and K. Moore for taxonomic assistance; A. Agron, K. Berry, E. Innocenti, C. MacRae and S. Peacock for the mineralogical and chemical analyses; R. Matear for discussions about historical shifts in the ASH; E. Butler for advice on measuring organic fractions in corals; M. Keith and the Woods Hole Advanced Imaging and Visualization Laboratory for photographic expertise; and N. Bax, J. Guinotte, R. Matear and 2 anonymous referees for comments on the manuscript. Components of this work were supported by the National Science Foundation; the Australian Department of Environment, Water, Heritage, and the Arts; the Australian Climate Change Science Program; the Australian Commonwealth Environmental Research Fund; and a grant of ship time by the Australian National Research Facility.

\section{LITERATURE CITED}

Adkins JF, Boyle EA, Curry WB, Lutringer A (2003) Stable isotopes in deep-sea corals and a new mechanism for 'vital effects'. Geochim Cosmochim Acta 67:1129-1143

Althaus F, Williams A, Schlacher TA, Kloser RJ and others (2009) Impacts of bottom trawling on deep-coral ecosystems of seamounts are long-lasting. Mar Ecol Prog Ser 397:279-294

Bibby R, Cleall-Harding P, Rundle S, Widdicombe S, Spicer $\mathrm{J}$ (2007) Ocean acidification disrupts induced defences in the intertidal gastropod Littorina littorea. Biol Lett 3: 699-701

Cairns SD, MacIntyre IG (1992) Phylogenetic implications of calcium carbonate mineralogy in the Stylasteridae (Cnidaria: Hydrozoa). Palaios 7:96-107

CARINA Group (2010) Carbon in the Southern Ocean region - the CARINA project: results and data, Version 1.1. Carbon Dioxide Information Analysis Center, Oak Ridge National Laboratory, US Department of Energy, Oak Ridge, TN

Clementson LA, Parslow JS, Griffiths FB, Lyne VD and others (1998) Controls on phytoplankton production in the Australasian sector of the subtropical convergence. Deep-Sea Res I 45:1627-1661

Cohen AL, Holcomb M (2009) Why corals care about acidification. Oceanography 22:118-127

Cohen AL, McConnaughey TA (2003) Geochemical perspectives on coral mineralisation. In: Dove PM, Weiner S, de Yoreo JJ (eds) Reviews in mineralogy and geochemistry, Vol 54. Mineralogical Society of America, New York, NY, p 151-187

Cohen AH, McCorkle DC, de Putron S, Gaetani GA, Rose KA (2009) Morphological and compositional changes in the skeletons of new coral recruits reared in acidified seawater: insights into the biomineralisation response to ocean acidification. Geochem Geophys Geosyst 10: Q07005

> De'ath G, Lough JM, Fabricius KE (2009) Declining coral calcification on the Great Barrier Reef. Science 323: 116-119

Dickson AG, Millero FJ (1987) A comparison of the equilibrium constants for the dissociation of carbonic acid in seawater media. Deep-Sea Res A 34:1733-1743 (Corrigenda: Deep-Sea Res A 36:983)

Dickson AG, Sabine CL, Christian JR (eds) (2007) Guide to best practices for ocean $\mathrm{CO}_{2}$ measurements. PICES Spec Publ 3. North Pacific Marine Science Organization (PICES), Sidney, BC

> Ellis RP, Bersey J, Rundle SD, Hall-Spencer JM, Spicer JI (2009) Subtle but significant effects of $\mathrm{CO}_{2}$ acidified seawater on the embryos of the intertidal snail, Littorina obtusata. Aquat Biol 5:41-48

Fautin DG, Guinotte JM, Orr JC (2009) Comparative depth distribution of corallimorpharians and scleractinians (Cnidaria: Anthozoa). Mar Ecol Prog Ser 397:63-70

Feely RA, Sabine CL, Lee K, Berelson W, Kleypas J, Fabry 
VJ, Millero FJ (2004) Impact of anthropogenic $\mathrm{CO}_{2}$ on the $\mathrm{CaCO}_{3}$ system of the oceans. Science 305:362-366

- Guinotte JM, Fabry VJ (2008) Ocean acidification and its potential effects on marine ecosystems. Ann NY Acad Sci 1134:320-342

Guinotte JM, Cairns S, Freiwald A, Morgan L, George R (2006) Will human-induced changes in seawater chemistry alter the distribution of deep-sea scleractinian corals? Front Ecol Environ 4:141-146

Hall-Spencer JM, Rudolpho-Metalpa R, Martin S, Ransome E and others (2008) Volcanic carbon dioxide vents show ecosystem effects of ocean acidification. Nature 454: 96-99

Havenhand JN, Buttler FR, Thorndyke MC, Williamson JE (2008) Near-future levels of ocean acidification reduce fertilization success in a sea urchin. Curr Biol 18: R651-R652

> Hein J, Conrad TA, Staudigel H (2010) Seamount mineral deposits. Oceanography 23:184-189

> Hoegh-Guldberg O, Mumby PJ, Hooten AJ, Steneck RS and others (2007) Coral reefs under rapid climate change and ocean acidification. Science 318:1737-1742

> Holcomb M, McCorkle DC, Cohen AL (2010) Long-term effects of nutrient and $\mathrm{CO}_{2}$ enrichment on the temperate coral Astrangia. J Exp Mar Biol Ecol 386:27-33

Koslow JA, Gowlett-Holmes K, Lowry JK, O'Hara T, Poore GCB, Williams A (2001) Seamount benthic macrofauna off southern Tasmania: community structure and impacts of trawling. Mar Ecol Prog Ser 213:111-125

Langdon C, Atkinson MJ (2005) Effect of elevated $\mathrm{pCO}_{2}$ on photosynthesis and calcification of corals and interactions with seasonal change in temperature/irradiance and nutrient enrichment. J Geophys Res 110:C09S07, doi:10.1029/2004JC002576

Lewis E, Wallace DWR (1998) Program developed for $\mathrm{CO}_{2}$ system calculations. ORNL/CDIAC-105. Carbon Dioxide Information Analysis Center, Oak Ridge National Laboratory, US Department of Energy, Oak Ridge, TN

Lowenstam HA, Weiner S (1989) On biomineralization. Oxford University Press, Oxford

> Maier C, Hegeman J, Weinbauer MG, Gattuso JP (2009) Calcification of the cold-water coral Lophelia pertusa under ambient and reduced $\mathrm{pH}$. Biogeosciences 6: 1671-1680

Maynard JA, Baird AH, Pratchett MS (2008) Revisiting the Cassandra syndrome: the changing climate of coral reef research. Coral Reefs 27:745-749

- McConnaughey $\mathrm{T}(1989){ }^{13} \mathrm{C}$ and ${ }^{18} \mathrm{O}$ isotopic disequilibrium in biological carbonates: 1. Patterns. Geochim Cosmochim Acta 53:151-162

- Mehrbach C, Culberson CH, Hawley JE, Pytkowicz RN (1973) Measurement of the apparent dissociation constants of carbonic acid in seawater at atmospheric pressure. Limnol Oceanogr 18:897-907

- Morse J, Andersson AJ, Mackenzie FT (2006) Initial responses of carbonate-rich shelf sediments to rising atmospheric $p \mathrm{CO}_{2}$ and 'ocean acidification': role of high Mg-calcites. Geochim Cosmochim Acta 70:5814-5830

Moy AD, Howard WR, Bray SG, Trull TW (2009) Reduced calcification in modern Southern Ocean planktonic formaminifera. Nat Geosci 2:276-280

Munday P, Dixson DL, Donelson JM, Jones GP, Pratchett MS, Devitsina G, Doving KB (2009) Ocean acidification impairs olfactory discrimination and homing ability in a marine fish. Proc Natl Acad Sci USA 106:1848-1852

> Noe SU, Dullo WC (2006) Skeletal morphogenesis and growth mode of modern and fossil deep-water isidid gorgonians (Octocorallia) in the west Pacific (New Zealand and Sea of Okhotsk). Coral Reefs 25:303-320

Orr JC, Fabry VJ, Aumont O, Bopp L and others (2005) Anthropogenic ocean acidification over the twenty-first century and its impact on calcifying organisms. Nature 437:681-686

Poloczanska ES, Babcock RC, Butler A, Hobday AJ and others (2007) Climate change and Australian marine life. Oceanogr Mar Biol Annu Rev 45:407-478

> Rex MA, Etter RJ, Morris JS, Crouse J and others (2006) Global bathymetric patterns of standing stock and body size in the deep-sea benthos. Mar Ecol Prog Ser 317:1-8

Riegl B, Bruckner A, Coles SL, Renaud P, Dodge RE (2009) Coral reefs: threats and conservation in an era of global change. Ann NY Acad Sci 1162:136-186

Ries JB, Cohen AL, McCorkle DC (2010) A nonlinear calcification response to $\mathrm{CO}_{2}$-induced ocean acidification by the coral Oculina arbuscula. Coral Reefs 29:661-674

> Roark EB, Guilderson TP, Flood-Page S, Dunbar RB, Ingram BL, Fallon SJ, McCulloch M (2005) Radiocarbon-based ages and growth rates of bamboo corals from the Gulf of Alaska. Geophys Res Lett 32:L04606

Roberts JM, Wheeler AJ, Freiwald A, Cairns SD (2009) Cold-water corals. Cambridge University Press, Cambridge

Sherwood OA, Thresher RE, Fallon SJ, Davies DM, Trull TW (2009) Multi-century time-series of ${ }^{15} \mathrm{~N}$ and ${ }^{14} \mathrm{C}$ in bamboo corals from deep Tasmanian seamounts: evidence for stable oceanographic conditions. Mar Ecol Prog Ser 397:209-218

Thresher RE (2009) Environmental and compositional correlates of growth rate in deep-water bamboo corals (Gorgonacea; Isididae). Mar Ecol Prog Ser 397:187-196

Thresher RE, MacRae CM, Wilson NC, Gurney R (2007) Environmental effects on the skeletal composition of deep-water gorgonians (Keratoisis spp.; Isididae). Bull Mar Sci 81:409-422

Thresher RE, Wilson NC, MacRae CM, Neil H (2010) Temperature effects on the calcite skeletal composition of deep-water gorgonians (Isididae). Geochim Cosmochim Acta 74:4655-4670

Thresher RE, Adkins J, Fallon SJ, Gowlett-Holmes K, Althaus F, Williams A (2011a) Extraordinarily high biomass benthic community on Southern Ocean seamounts. Sci Rep (Nature) 1:119, doi: 10.1038/sprep00119

Thresher RE, Adkins J, Thiagarajan N (2011b) Modal analysis of the deep-water solitary scleractinian, Desmophyllum dianthus, on SW Pacific seamounts: inferred recruitment periodicity, growth, and mortality rates. Coral Reefs 30:1063-1070

Turley CM, Roberts JM, Guinotte JM (2007) Corals in deepwater: will the unseen hand of ocean acidification destroy cold-water ecosystems? Coral Reefs 26:445-448

Veron JEN, Hoegh-Guldberg O, Lenton TM, Lough JM and others (2009) The coral reef crisis: the critical importance of $<350 \mathrm{ppm} \mathrm{CO}_{2}$. Mar Pollut Bull 58:1428-1436

White M, Bashmachnikov I, Aristegui J, Martins A (2007) Physical processes and seamount productivity. In: Pitcher TJ, Morato T, Hart PJB, Clark MR, Haggan N, Dantos RS (eds) Seamounts: ecology, fisheries and conservation. Blackwell, Oxford, p 65-84 